\title{
Situation Analysis and Countermeasure of Environmental Accounting Disclosure in Listed State-owned Steel Enterprises
}

\author{
Lin Chen ${ }^{1, a}$ \\ ${ }^{1}$ Business School of Sichuan University, Chengdu, P. R. China, 610064 \\ a450503911@qq.com
}

\begin{abstract}
Keywords: State-owned Steel Enterprise, Listed Enterprise, Environmental Accounting Information Disclosure.
\end{abstract}

\begin{abstract}
With the rapid development of economy, the social demand for resources is increasing, so the environmental pollution is becoming more and more serious, and Eco-issues has become the focus of national attention from all walks of life. Through collecting the annual report and the disclosure of social responsibility report of listed state-owned steel enterprises in 2009-2013, in this paper, it is shown in the form of chart that the environmental accounting information of listed state-owned steel enterprise in our country is announced in the contents and the way, and the constructive suggestions is also offered relatively. Steel enterprises should belong to the series of heavy pollution enterprises, and study on the state-owned steel enterprise is benefit to improve the environmental accounting information disclosure of the whole steel enterprise and promote the environmental protection consciousness of the steel enterprises.
\end{abstract}

\section{Introduction}

Once Chai Jing published "dome under" in February 2015, it caused the thinking of all parties. Because of the effect of haze, the phenomenon of air quality index fall has not only exists in first-tier cities, such as Beijing and Shanghai, all cities in the country also have appeared the serious phenomenon of haze. However, the reason resulting in this phenomenon is that the seriousness of environmental pollution. A series of pollution issues, such as Bohai gulf oil spill, Zijin mining pollution events and so on, cause the attention of government and other stakeholders to the enterprise environmental accounting information disclosure.

In our country, Environmental accounting has begun to be paid attention in the early 1990 s, which is a new research field, but its research on the theory and practice is lagging. Jiashu Ge (1992) specifically proposes the related theory on the environment accounting for the first time ${ }^{[1]}$. Yijun Chu (1999) considers that environmental information disclosure is mainly disclosed in the board report, the financial statements and notes, including the environmental spending and liabilities accounted into current profit or loss. In recent years, empirical study on the influencing factors of environmental accounting disclosure is more and more $^{[3]}$. Fanli Meng (1999) summarizes the content of environmental accounting information disclosure including the financial impact and environmental performance of environmental problems, and the financial data caused by environmental problems can be disclosed or improved in the existing financial report ${ }^{[2]}$. Sugang Zhang and Hongliang Zhang (2009) suggest that environmental accounting information disclosure should adopt the combination of the statement note and single environment report. For the content of environmental report, Jianfa Li (2002) and other scholars believe that the best way of environmental accounting information disclosure is the environmental financial effect and non-financial effect, which is the combination of qualitative and quantitative way, respectively. Jianxin Geng, etc(2002) puts forward the environmental information disclosure should include environmental problems and its influence and the plan of environment countermeasure, and the financial statement and note should focus on the disclosure of environmental expenditure and environmental liabilities. Jinbin Liu (2013) has discovered: (1) the reliability of enterprise environment accounting information is poor, mainly qualitative; (2) the content of disclosure is scattered, non-standard and lack of comparability; (3) the disclosure is inadequate and incomplete; (4) the disclosure of information is not fair; (5) the disclosure of enterprise environment accounting information is different in all the industry, and its disclosure cost is relatively high in the heavy pollution industry. Linfeng Jiang (2010), Yingping Zhang (2012) and so on 
think that the consciousness of enterprise environmental accounting information disclosure is not strong; the scope of subject is narrow; the level of disclosure is not high; most companies lack the initiative and enthusiasm of disclosure.

In conclusion, the research on the status of the environmental accounting information disclosure of state-owned steel enterprises is less, and steel enterprises, which are one of the heavy pollution industries, are the national foundational pillar industry. The study on the environmental accounting disclosure and the suggestions put forward relatively can help to improve the completeness of steel enterprise environment accounting information disclosure, which is helpful to all the stakeholders.

\section{Present situation of Environmental Accounting Information Disclosure of Listed State-owned Steel Enterprises}

\section{Sample Selection and Data Sources}

For the comparability of data, the data of ST and * ST companies are deleted in the paper. 28 state-owned steel enterprises listed on Shanghai and Shenzhen are selected as the object of research, and the content and mode of environmental accounting information disclosure in these enterprises from 2009 to 2013 are analyzed. All the data come from Shenzhen Stock Exchange, Shanghai Stock Exchange, Tide of Information Network, the web site of listed company.

\section{Analysis of Present Situation of Environmental Accounting Information Disclosure of Listed State-owned Steel Enterprises}

A large amount of literatures show that the way of the enterprises environmental accounting information disclosure mainly includes prospectus, annual report and independent report. As shown in table 1, listed state-owned steel enterprises mainly disclose it in the board report and the note of financial statement, which is mostly qualitative description. Only a handful of enterprises choose to disclose it in the corporate governance, and the content of disclosure is the internal control implementation simply referring to the smooth development of the work of environmental protection, which has a little reliability and usefulness. $90 \%$ of the enterprises disclose environmental accounting information in the prospectus, but its quality isn't high. Now more than half of the enterprises choose to disclose independent environmental report, which shows that state-owned steel enterprises pay more and more attention to the environmental information disclosure. Shanxi taigang stainless steel co., LTD also reveals the environmental performance, pollutant emission target, environmental performance of energy in the environmental report, which is combined with the quantitative and qualitative way.

Tab. 1 the way of information disclosure

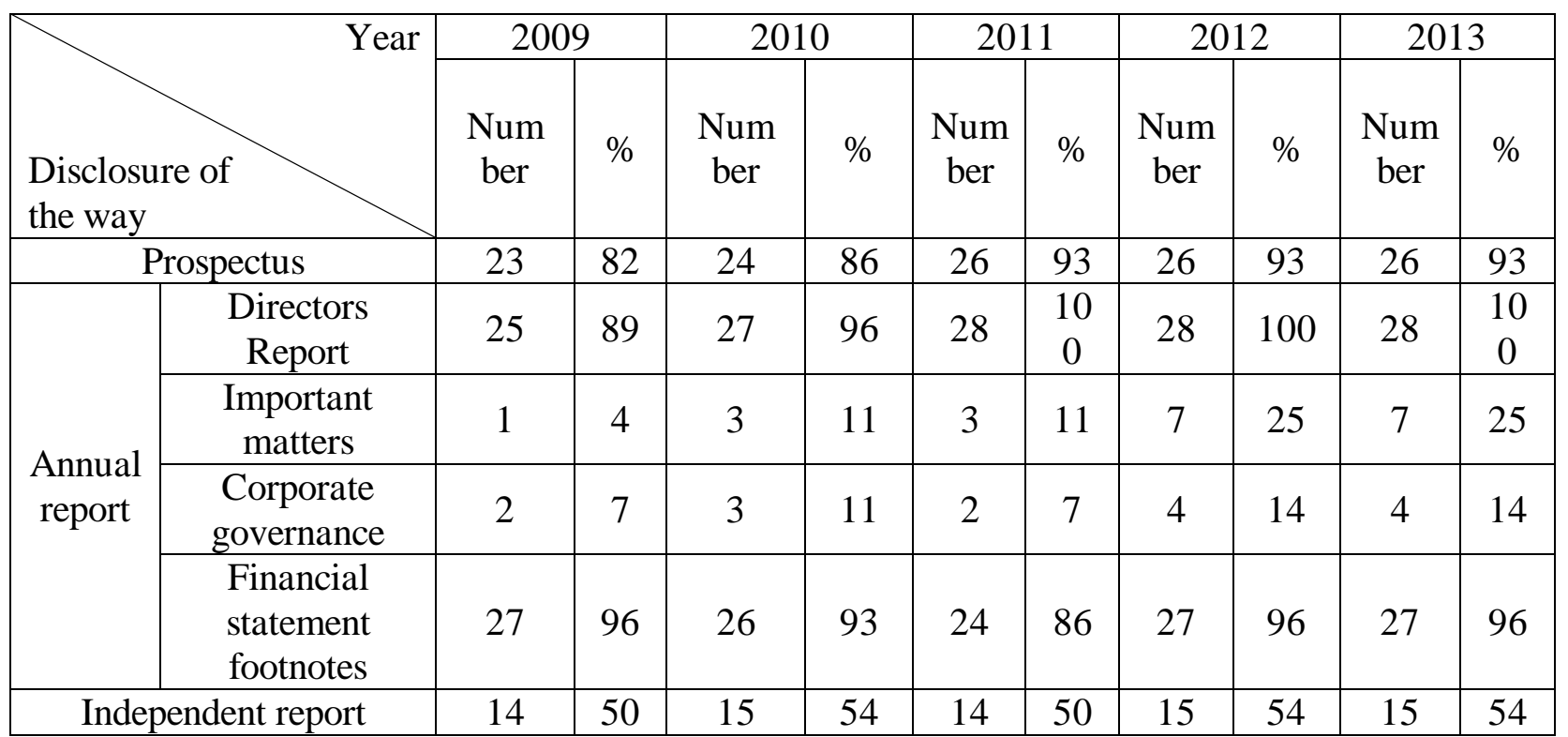


Tab. 2 the content of information disclosure

\begin{tabular}{|c|c|c|c|c|c|c|c|c|c|c|}
\hline \multirow{2}{*}{ Year } & \multicolumn{2}{|c|}{2009} & \multicolumn{2}{|c|}{2010} & \multicolumn{2}{|c|}{2011} & \multicolumn{2}{|c|}{2012} & \multicolumn{2}{|c|}{2013} \\
\cline { 2 - 14 } & $\begin{array}{c}\text { Num } \\
\text { Der } \\
\text { the content }\end{array}$ & $\%$ & $\begin{array}{c}\text { Num } \\
\text { ber }\end{array}$ & $\%$ & $\begin{array}{c}\text { Nu } \\
\text { mb } \\
\text { er }\end{array}$ & $\%$ & $\begin{array}{c}\text { Nu } \\
\text { mbe } \\
\text { r }\end{array}$ & $\begin{array}{c}\text { Num } \\
\text { ber }\end{array}$ & $\%$ \\
\hline $\begin{array}{c}\text { Environmental protection } \\
\text { investment }\end{array}$ & 22 & 79 & 22 & 79 & 23 & 82 & 23 & 82 & 23 & 82 \\
\hline $\begin{array}{c}\text { Environmental protection grant, } \\
\text { subsidy and tax breaks }\end{array}$ & 12 & 43 & 15 & 54 & 18 & 64 & 23 & 82 & 23 & 82 \\
\hline Litigation, reparations & 0 & 0 & 0 & 0 & 0 & 0 & 0 & 0 & 1 & 4 \\
\hline Discharge fee and afforestation fee & 13 & 46 & 15 & 54 & 13 & 46 & 14 & 50 & 12 & 43 \\
\hline $\begin{array}{c}\text { Resource tax and resource } \\
\text { compensation }\end{array}$ & 4 & 14 & 5 & 18 & 7 & 25 & 8 & 32 & 8 & 32 \\
\hline ISO related certification & 7 & 25 & 7 & 25 & 8 & 29 & 18 & 64 & 16 & 57 \\
\hline Environmental reward & 8 & 29 & 9 & 32 & 12 & 43 & 17 & 61 & 17 & 61 \\
\hline Policy implication & 18 & 64 & 20 & 71 & 20 & 71 & 27 & 96 & 25 & 89 \\
\hline Environmental loan & 8 & 29 & 6 & 21 & 6 & 21 & 10 & 36 & 9 & 32 \\
\hline
\end{tabular}

As shown in table 2, as a whole, the increasing of proportion of environmental accounting information disclosure illustrates that state-owned steel enterprise in our country is paying more attention to the environmental disclosure. The proportion of the disclosure of government environmental subsidies and tax breaks is increasing year by year, and it shows the government strongly encourages the relevant company to take environmental protection measures and gives a certain amount of money to support it. From the perspective of the content of disclosure, the state-owned steel enterprises mainly disclose environmental information beneficial to the enterprise, but the lawsuits of environmental protection and the information of indemnity almost isn't disclosed. Although the proportion of state-owned steel enterprise disclosing resource tax is increasing year by year, the companies that has disclosed it is little, and there was only eight enterprises in 2013. Most state-owned steel enterprises in China mainly disclose the qualitative contents, and the information disclosed is mostly related to historical information and the future information, such as the potential influence of environment, is less to be disclosed.

\section{Existing Problems of Listed State-owned Steel Companies on the Environmental Accounting Information Disclosure}

\section{The Consciousness of Social Responsibility Report Disclosure is not Strong and Independent Report Is Less}

Steel enterprises in some countries, such as the USA and Japan, always compile independent environmental report combined the qualitative and quantitative description together. Only a few state-owned steel enterprises in China compile independent environmental report mainly including the qualitative description whose usefulness is not high.

\section{The Qualitative Description Is in the Majority in the Environmental Accounting Information} Disclosure and the Quantitative Description Is Less

The quantitative and useful information, such as environmental asset, environmental liability, resource tax and environment cost in the financial statements, is disclosed very less. The monetary information is mainly disclosed in the simple quantization, and the asset and liability related to environment is very less to be disclosed, which is lack of reliability and usefulness.

\section{Environmental Accounting Information Disclosure is More Historical Information}

The content disclosed by 28 listed state-owned steel companies mostly reflect the past events, such as tax deduction and exemption, the influence of policy and pollutant charge, etc. For environmental 
protection investment and major environmental matters, most companies only illustrate with simple text, and the influence of these matters on the recent and future development of enterprise is mentioned rarely and there are also few companies analyzing a cost-benefit of major environmental protection project. The above condition makes the practicality of enterprise environmental accounting information disclosure poor and lack of relevance, which make the user of accounting information can't truly understand the present situation of the environmental investment or governance and make a realistic evaluation of the enterprises.

Message that is Positive and Benefit to the Development of Enterprise Is More Disclosed in Environmental Accounting Information Disclosure and Negative Information Is Rarely Involved

In the environmental accounting information disclosure of 28 listed state-owned steel enterprises, the positive message, such as the measures and achievement of environmental management and protection, tax incentive, etc, is disclosed more, and the damage to environment in the process of the production and operation of the enterprise, the punishment of environmental protection and other negative environment information are involved rarely.

\section{Suggestions to Perfect Environment Accounting Information Disclosure of State-owned Steel Enterprise}

The Government Should Strengthen the Publicity and Management of Environmental Information Disclosure to Improve the Environmental Protection Consciousness of Enterprise and Social Public and Guide Enterprise to Voluntarily Disclose Relevant Information

Although our country has introduced a series of policies to protect environment, which has achieved some good results. However, as a whole, the social responsibility of enterprise is not enough and the environmental awareness of social public still need to be improved. Therefore, the government should further improve the consciousness of environmental protection of social public and strengthen the social responsibility of enterprises. For environmental accounting information disclosure, the government should guide the enterprises to transfer from mandatory disclosure to conscious disclosure and gradually form a mature disclosure mode of environmental accounting information, which could promote the long-term stable development of our economy.

The government should strengthen the propaganda of environmental information disclosure, and the relevant government department and social intermediary institution must strengthen the supervision to the behavior of enterprise. Furthermore, it is necessary for the government to carry out the authoritative seminars of environmental accounting theoretical research and invite leaders and financial officers of big companies to participate in the seminars. Thirdly, the degree of industry personnel paying attention to the environmental information disclosure can be improved.

\section{The Government Should Perfect the Laws and Regulations Related to Enterprise Environment Accounting Information Disclosure}

The government should formulate a special standard of environmental accounting disclosure and disclosure mode of independent environmental accounting, such as environmental asset and liability included in the accounting elements and becoming a part of balance sheet. Furthermore, the environmental protection laws and regulations formulated by the government should pay more attention to the economic compensation and other compensation of the victims. At last, the government should strengthen penalty to make the enterprises pay more attention to protect the environment.

\section{Perfecting the Accounting Laws and Regulations, Unifying Specific Norms and Requirements of Environmental Accounting Information Disclosure}

(1) The content and scope of environment accounting information disclosure should be put forward clearly. It is very important to build a complete content of environmental accounting information disclosure, and the content of the environmental accounting information disclosure mainly contains the information of environmental protection and resource conservation. These two aspects should include the 
financial impact of environment, performance information, the financial impact of resource and the performance information of resource. The circumstance of the pollution to the ecological environment, environmental liability, etc, should be disclosed by enterprises, once these information are included, it can effectively promote the harmonious development of economy, resources and environment, which is the true sense of environmental accounting information.

(2) The form of environmental accounting information disclosure should be confirmed. All the companies should disclose environment decision-makings communicated with director in the process of corporate governance, and the enterprises should develop independent environmental report including the environmental policy, environmental objective, environmental protection information and environmental performance, etc.

\section{Setting up Environmental Auditing Department, Strengthening the Supervision to the Environment}

Considering the cost problem and enterprise image, the for-profit companies trend to avoid the disclosure of the fulfillment of environmental responsibility or distort the real environmental information of enterprise. In addition, due to the particularity of environmental resource, the monitoring to the enterprises need the cooperation of national audit department and environmental protection department, who formulate specific audit standard. Nowadays, Japan, Europe, United States and other countries have established the environmental audit department, which gradually become mature, but the environment audit in our country just start and it does not play a certainly supervisory role. Hence the country should set up special and independent environmental audit department to strengthen the management on the environmental disclosure and environmental behavior of corporation, which will make the enterprise pay more attention to environmental accounting information disclosure.

\section{References}

[1] Jiashu Ge, A New Ideological Trend of Western Accounting Theory in 1990s, J, Accounting Research, 5. (1992).

[2] Fanli Meng. Theory of Environmental Accounting Information Disclosure and its Related Theoretical Issues. Accounting Research, 4. (1999).

[3] Yijun Chu. Discussion of Enterprise Environmental Information Disclosure. Shanghai Accounting, 3. (1999). 